\title{
STUDIES ON THE PHYSIOLOGICAL HEARING LOSS BY AGE
}

\author{
By \\ KoKo YOKOUCHI \\ From the Department of Otolaryngology, Hirosaki University \\ School of Medicine, (Director: Prof. S. Awataguchi)
}

It has been well known that the hearing acuity of healthy persons become worse with the increase of age (so-called physiological hearing loss by age effect), and recently some workers published the idea that to evaluate the hearing loss due to the acoustic trauma and other etiologies in older pers. ons, this physiological loss must be subtracted from his audiometric loss of hearing. Considering this view hearing acuity was measured on 412 subjects without any subjective difficulty of hearing and any pathological changes of the ear. Subjects were divided into 15 groups of every five year, and the results were statistically discussed.

The main results obtained were as follows:

1) On the whole, the hearing acuity decreased gradually with the increase of age. This phenom. enon was not noticeable until about 50 years old, but became more distinct over this age.

2) Individual difference of the hearing loss also became larger with the increase of age, espe. cially in groups over 50 years old. Statistical significance calculated by variance ratio was found between the individual differences of nearly all groups over 50 years and that of younger groups.

3) Hearing acuity was impaired mainly in the high frequency region, and the gradual sloping form was predominantly found in the audiogram. Nearly all subjects showed the bilateral symmetrical audiogram in both ears. Femalle group showed a little less loss than the male group.

From the results mentioned above, following conclusions were drawn.

The changes of the hearing acuity by age manifest itself not only as the increase of the hearing loss but also as the increase of the individual difference among subjects in the same age group. So, in order to evaluate and define the physiological hearing loss by age, it is not fully adequate to take an account of only its mean value of the hearing loss.

\section{聴力の生理的年令変化について}

\section{弘前大学医学部耳㱵咽喉科学教室（主任：栗田口省吾教授）}

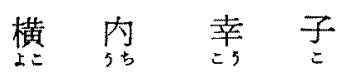



第 3 項 全周波数平均値の分散

第 4 項 性別炕上る聴力の相異

第 5 項 オージオグラムの型

第6 項 オージオグラムの対称性, 非対称性につい $\tau$

第4 等 総括业びに考按

第 5 娈 結 諭

第6 章 交献 


\section{第 1 章 緒 言}

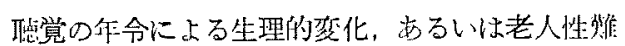
恥の問題については，既に古くより多くの研究報齿 がなされてをり，その大要は既に明らかにされてい る.しかし乍ら最近特に他の疾舮との関連におい て，高令者の聴力を検討する必要が增して来て，そ の実態のより精密な研究が要求されるよらになつ た. 特に騒音による職業性難聪の問題，湸中，㷋寒 補償をめぐつて, 生理的德力損失の正確な把握が強 く望まれるよらになつて来た，即ち，騷音環境作絜 者の聴力僨害を問題にする場合に，その中に含を机 ているはづの生理的損失を，老の難浡度加控除す べきであるという考克である。この考充は近年では 一般に承認されたような状勢であり，中でも Davis (1960) は，その经青補償をめぐつて，聴力椇傷度 の算定の際，数式をるつて生理的変化による恥力鋀 失度を差引く方法を発表した，しかし年令による聴 力の变化は，年令の進むにつれて個人差が大きくな り，年令に上る鲰力低下笚なる平均値をもつては 示し難く，又生理的聴力損失度の算定方法にも幾多 問題があると思われる、そこで著者は，高令者にお ける聴力変化の実態をより詳細に把握するために， 10 才から92才迄の広い年代を 5 才づつに分類し， 聴力の推移と分散を細かく求め二三の知見を得る束 ができた。ここに報告して批判を得たいと思う。

\section{第 2 章 椮査対象並ひに梌查方法}

第 1 項 检查対象

青森県立中央病院耳劓咽院科外来を訪れた患者の 中, 德覚に関する自覚症, 聴力に影響を及ぼす上う な耳科的既往原がなく，耳鏡検查で㪗膜に病的所見 のない10才から92才迄412名824 耳に就て聴力检 查を行つた.

\section{第2項 梌查方法}

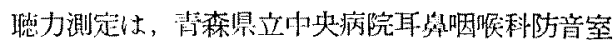
に扎いて、リオン $1013 \mathrm{~A}$ 型オージオメーターによ り行つた，梌应凩波数は 125, 250,500,800,1000， $1500,2000,3000,4000,6000,8000 \mathrm{cps}$ とL, 测定

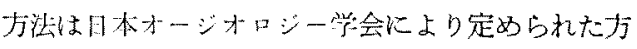
洁比徒った。

\section{第3 章 検査成綪}

企拉例を10〜14才，15１9才，20２4才，25〜 29才, 30〜34才, 35〜39才, 40〜44才, 45〜49 才, 50〜54才, 55〜59才, 60〜64才, 65〜69才,

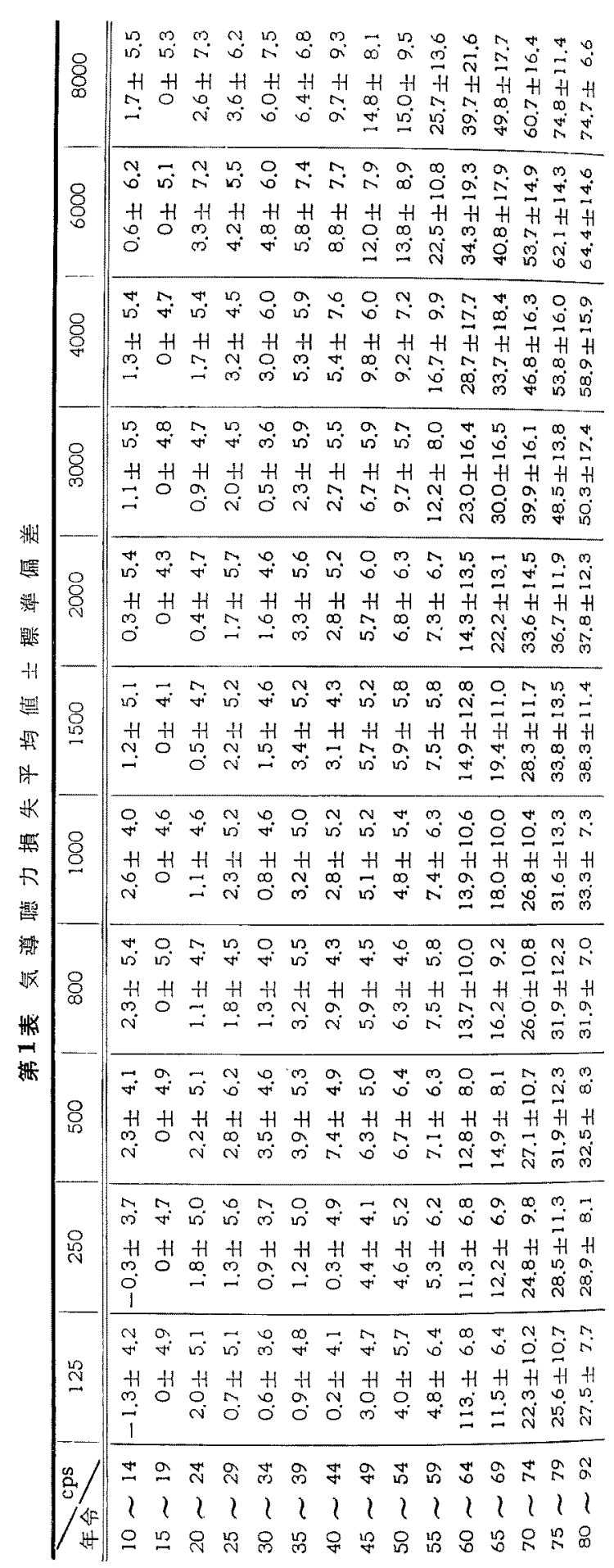


70〜74才，75〜79才，80〜92才の15 群に分けて検討 した. 10才から74才迄の13群は各々30名60耳, 75 〜79才は13名26耳，80〜92才は9名18耳であつた。 稣力損失值の検討に際しては，ずでて 15〜19才の群60 耳の平均値を Odbとして補正したものを用いた。

\section{第 ! 項 聴力損失平均值}

第 1 表は年代別気導聴力損失平均值及び標準偏差を， 一括して表にしたものである。第 1 䨓は平均値をオーシ オダラムにとつたものである．20代，30才代は10才代 に比して特に大きな変動はなく，40才を過ぎると極め て徐々に高音域，特に $8000 \mathrm{cps}$ 加ら聴力低下が年令上 共に見られるが，域値は 10db 以内である，45〜49才 では 6000cps, $8000 \mathrm{cps}$ の域值が 10db を越し, 55〜59 才では $3000 \mathrm{cps}$ 以上の高音域に著明な低下が認められ る.しかしこの年代迄は低音域に拈ける聴力の低下は軽 微である.この群を過ぎると年令の增加に対する域值の 上昇著明となり，又低音域の聴力も悪化を示すこの 状况を横軸に年令をとつて示すと，第 2 图の如く，域值 悪化の進行状況は 50 才迄のなだらかな悪化と，50才以 上の急激な悪化との 2 相を有する事が分る. しかし乍ら 70 才を過ぎると悪化の傾向はやや少くなり，80才以上 の群では75〜79才の群との間に著明な 差は認められな い.この現象は年令が㙕すにつれて，所謂 scale out 例が出現する事で悪い方の限界があるためとも考壳られ ない事はないが，同様な現象は scale out の例のない低 音域についても云えるので，必ずしるそれだけによるも のではないであろう，以上要約すれば40才頃から高音 域，特に $8000 \mathrm{cps}$ 加極めて徐々に聴力は低下して行 くが，極めて軽微であり，明睹な悪化は50才後半より 始まると云兄る、この現象は特に高音に行くに従つて著

第 1 图 平均值オージオグラム

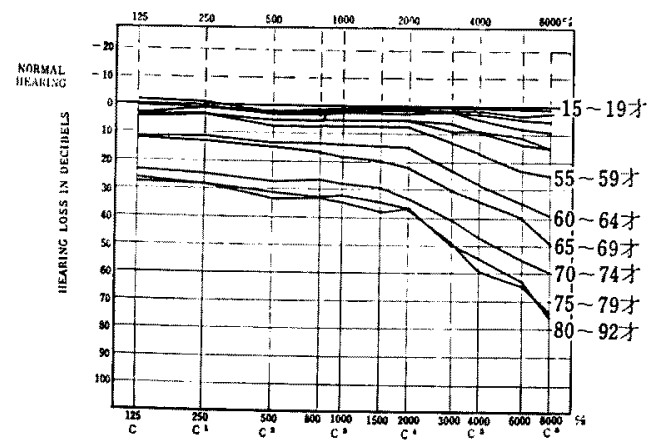

第 2 图 250，1000，4000cps に拈ける 域值 0 年令変化

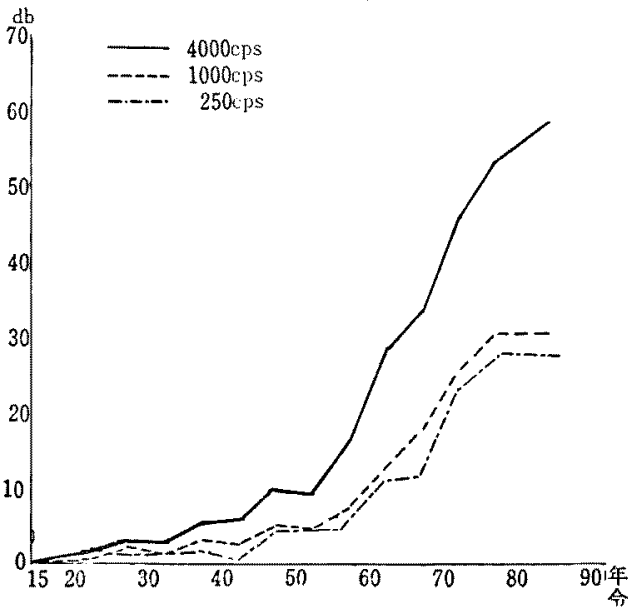

しい。しかし作ら80才を過ぎるともしろ聴力変化の程 度は軽微となる。

骨導についても同様な検討が行われたが，その成績は 気導と全く同等であつた

第 2 項 分 散

第3図加ら第 17 图迄は，各周波数に括ける聴力損失 値のばらつき scattergram にし，その不偏分散と 15 〜19 才の不偏 分散 との比 $\left(\mathrm{F}=\frac{\mathrm{u}^{2}}{\mathrm{v}^{2}} \mathrm{~F} \geqq 1\right)$ 学求め， その $\mathrm{F}$ 值を $\mathrm{F}$ 表によつて検定を行い，各年代別に記 した，轱軸に聴力損失值を $\mathrm{db}$ で表し，横軸に周波数を とつた.15〜19才では Odbを中心とした正規分布をな す20才以上になると高音域，特に $8000 \mathrm{cps}$ の分散が

第3 图各周波数の德力椇失值の分散 10〜14才 (60耳)

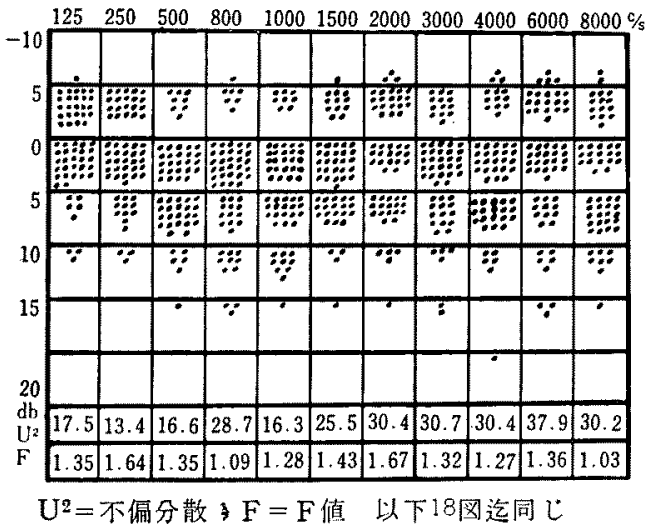


第 4 图各周波数の聴力損失値の分散 $15 \sim 19 才(60 耳)$

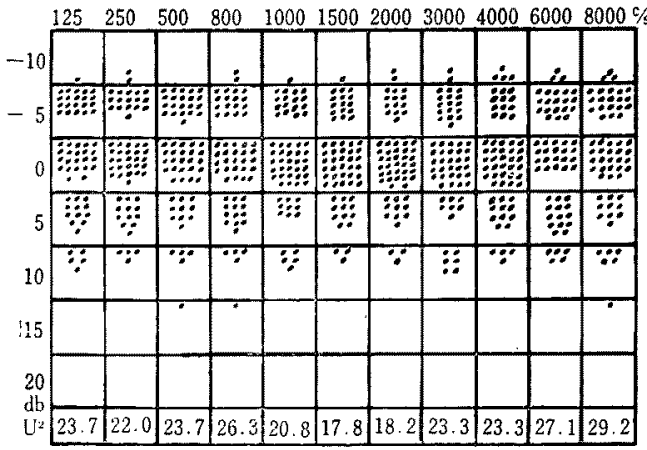

第 5 图各周波数の聴力椇失值の分散 20〜24才 (60耳)

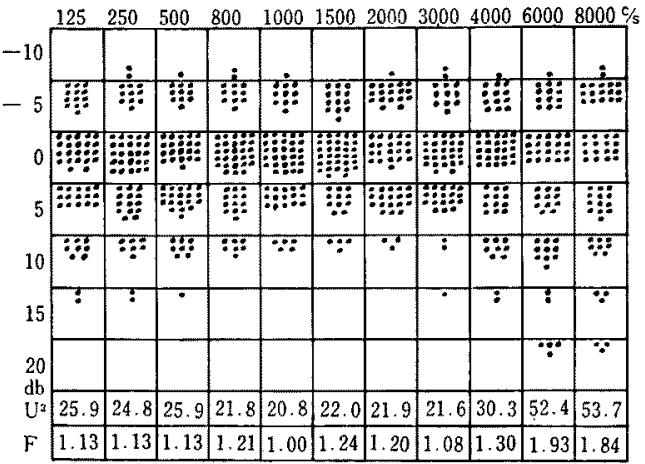

第 6 図各周波数の聴力損失値の分散 25 29才 (60耳)

$\begin{array}{llllllll}125 & 250 & 500 & 800 & 1000 & 1500 \quad 2000 & 3000 \quad 4000 \quad 6000 & 8000 \%\end{array}$

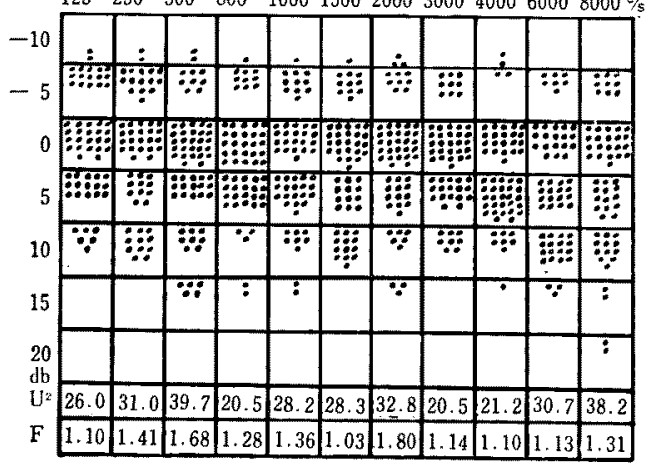

第 7 図各周波数の聴力損失值の分散 30 34才 (60耳)

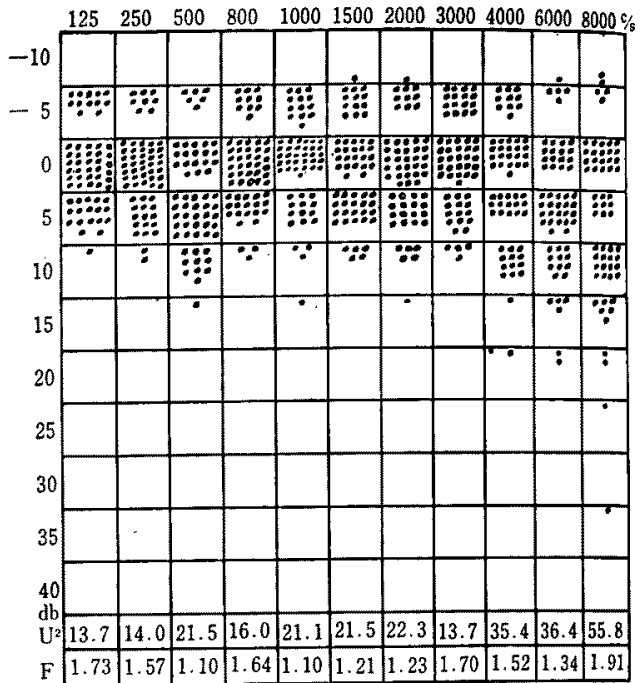

第 8 图 各吸波数の聴力損失值の分散 35 39才 (60耳)

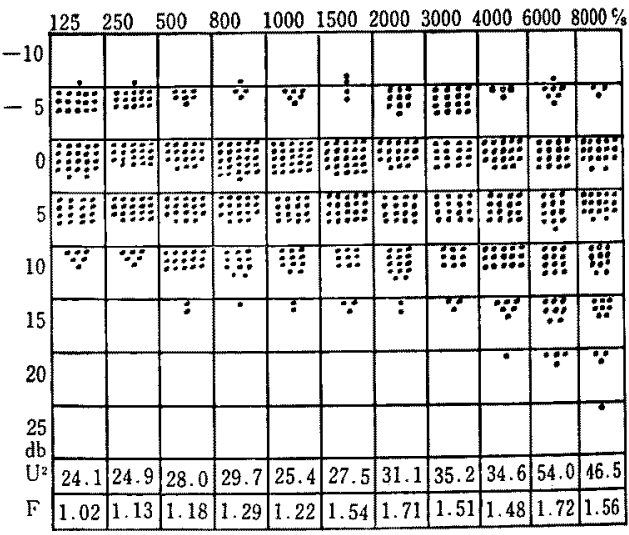

第9図各周波数の㯖力損失值の分散 $40 \sim 44$ 才 (60耳)

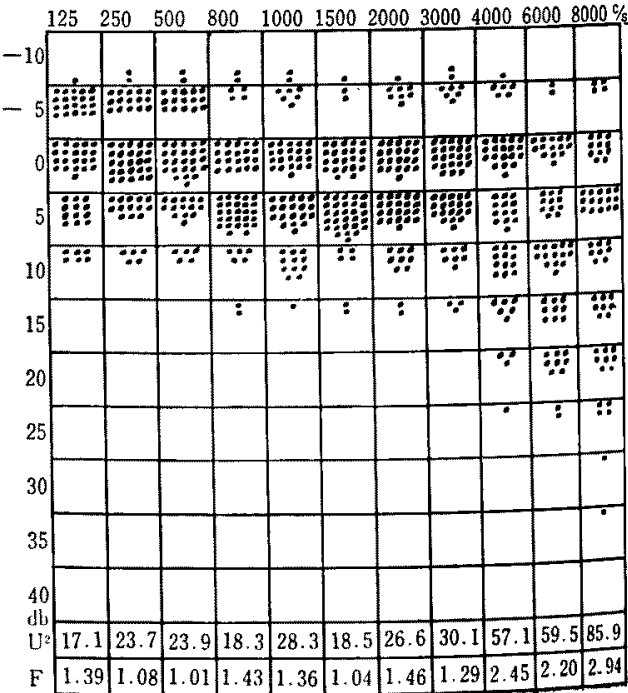


第10图 各周波数の栕力損失檤の分散 45 49才 (60耳)

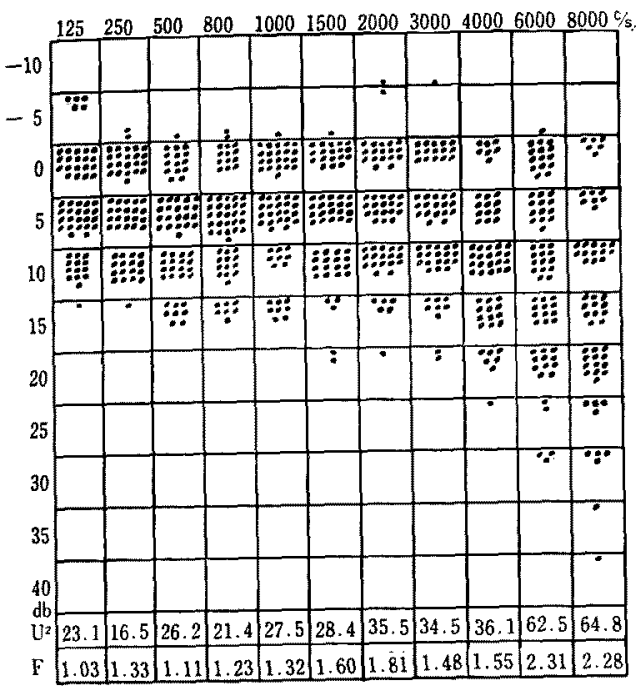

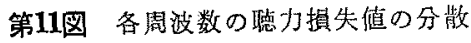
50 54才 (60耳)

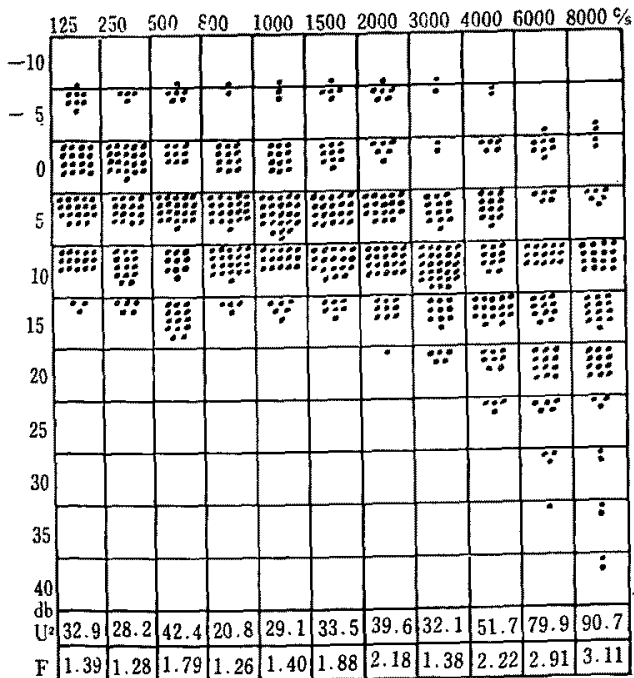

第12図 各周波数の聴力損失值の分散 55〜59才 (60耳)

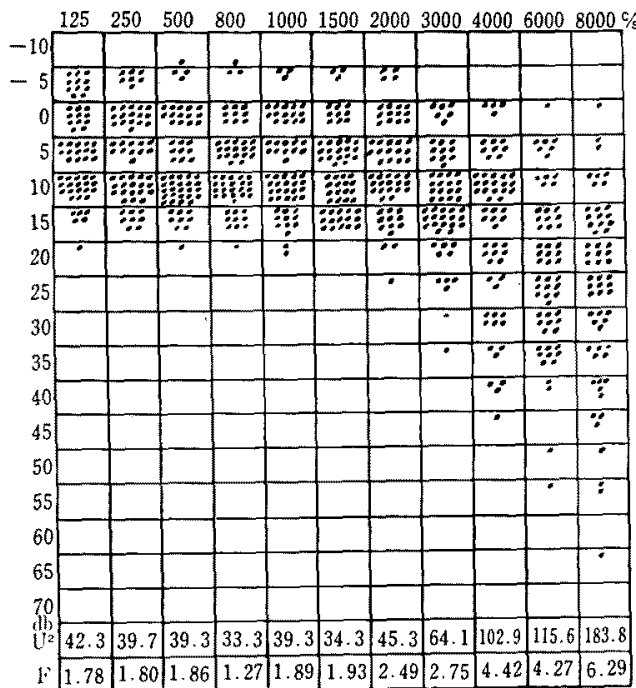

第13図 各周波数の聴力損失値の分散 60 64 万 (60耳)

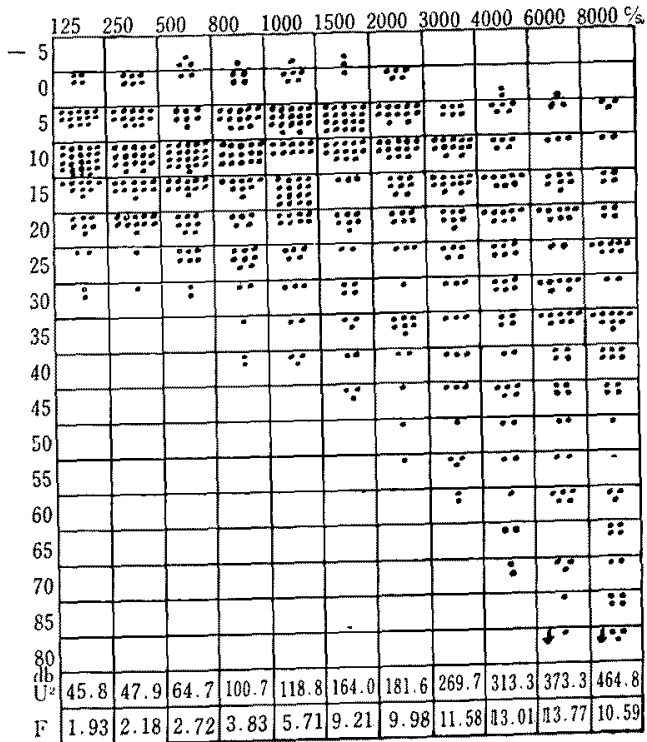


第14图 各周波数の㯖力損失値の分散 65 69才 (60耳)

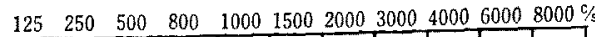

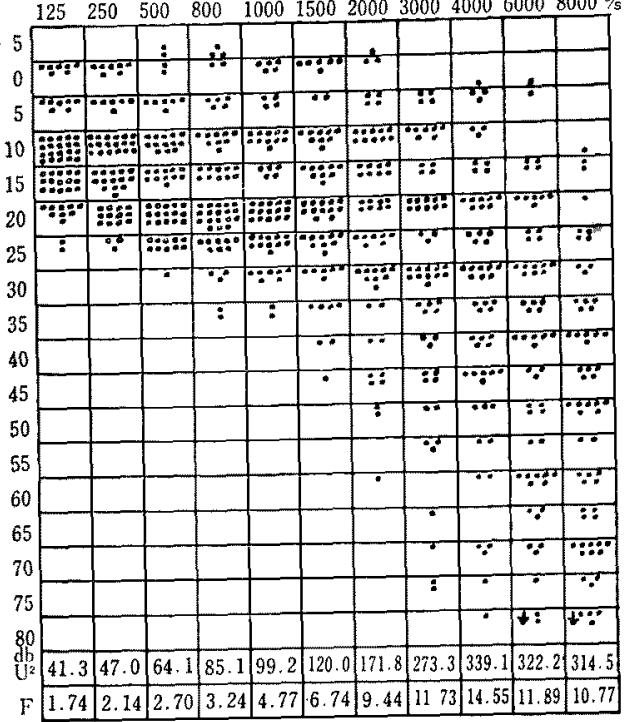

第15图各周波数の聴力損失值の分散 70〜74才 (60耳)

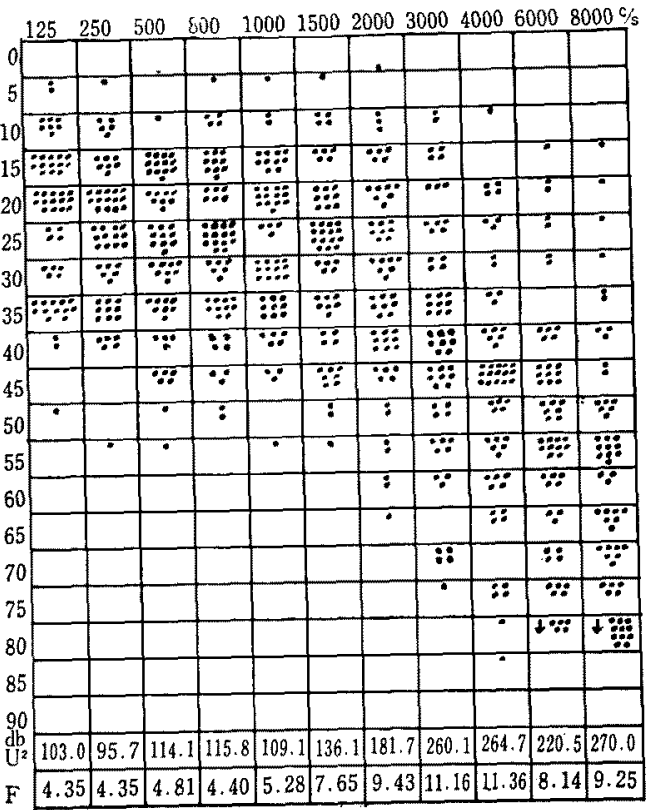

第16图 各周波数の僡力損失值の分散 75 79才 (26耳)

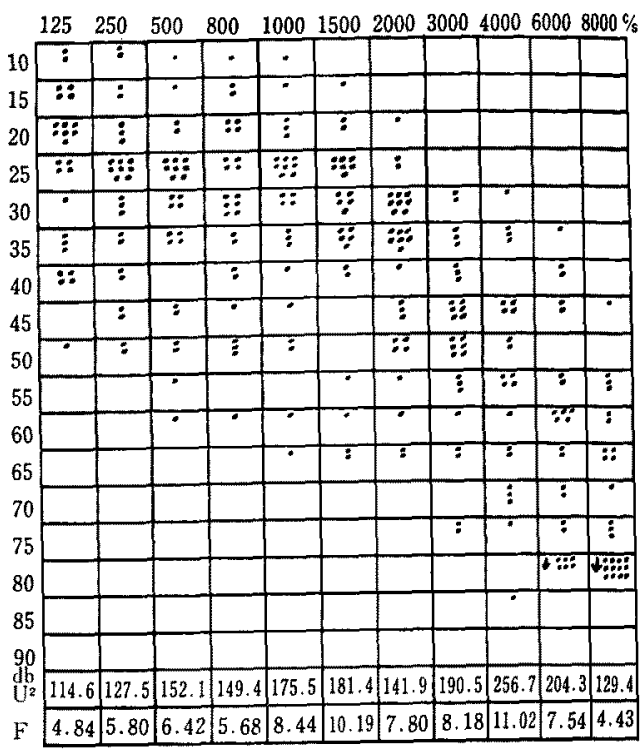

第17图 各周波数の㯖力賣失値の分散 80 92才 (18耳)

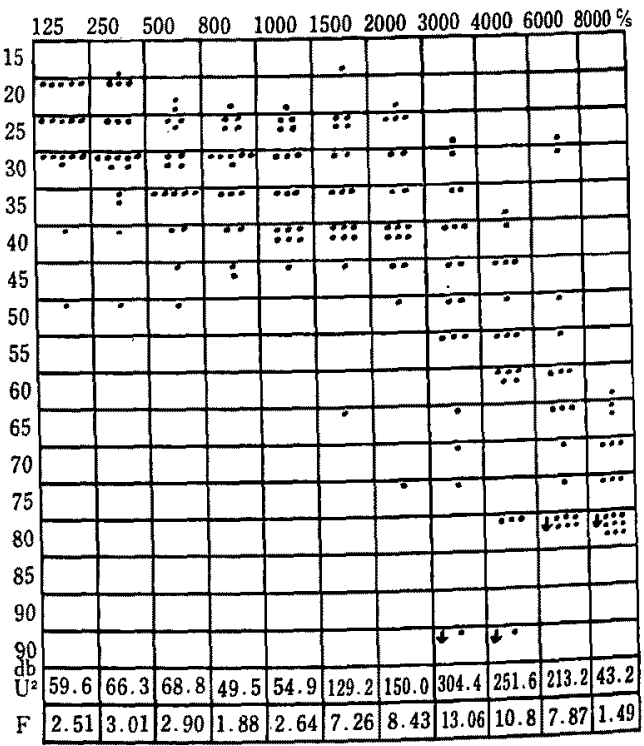


少しつ゚り大きくなつて行き，55〜59才になりその分散 は15 19才のそれと比較して，全周波数に有意の差を

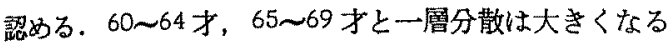
が, scale out が多くなる事と，聴力損失値が大きい力 に偏つて来るため，8000cps の F 值は逆に少くなつて いる.70〜74才，75〜79才，80〜92才と年令の多くな るとつれて， scale out の增加に上り分散は狭くなる。 要約すれば，年令の進むにつれて分散は大きくなり，分 有の形がくつれ，分散の点で同一母集団からの資料とは 考学難いといら結果となる．60〜69才では分散は最大 となるが，70才を過ぎると悪い方へ縮小し，分散は逆 に若干小さくなつていく.

\section{第 3 項 全周波数平均值の分散}

第 18 図は個々のオージオグラムの気道損失平均値 $(125,250,500,1000,2000,4000,8000$ の 7 周波数の平 均）をとり，各年代別に scattergram にし標準偏差を算 出したものである. 年令に伴う平均值の增加は云う迄む ないが，分散む大きくなり，50才以上では有意の羑が 認められる．60〜64才の分散は最大で，80〜92 才では 小さくなっている.

第18图 全周波数の域值の平均値の分散

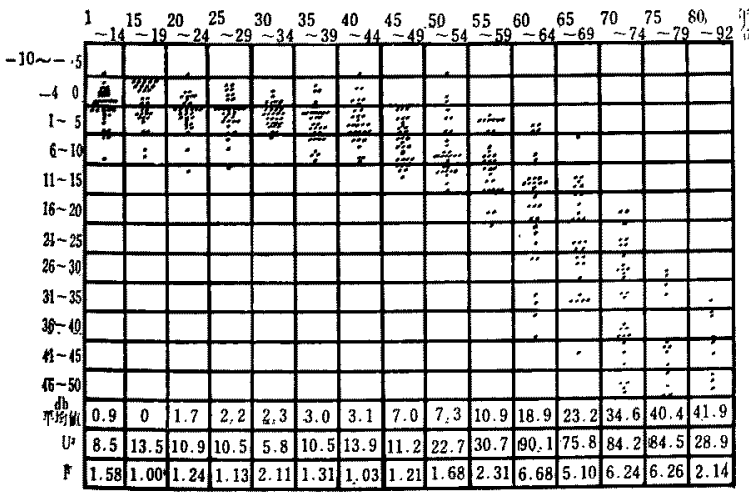

第 4 項 性別に上る聴力の相異

性别の平均值 オ゙ージオグラムは，第 19〜21 図に示し た．50才代は男の聴力は良好であるが60才以上では女 の㯖力の方がよい，50才代の聴力も $3000 \mathrm{cps}$ 以上では 女の方が良好である。

第 5 項 オージオグラムの型

20db 以内を正常耳とし，第 2 表の如く型を分類した。
第19図 性別による平均值オージオグラムの比較


男 - 女....

第20图 坐別による平均值オージオグラムの比較
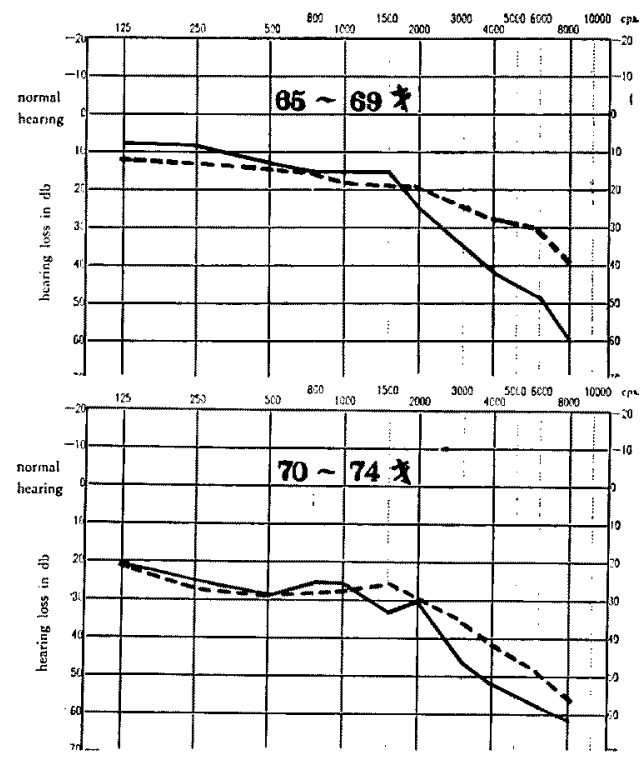

男 — 女 ..... 
第21図 性別による平均値オージオグラムの比較
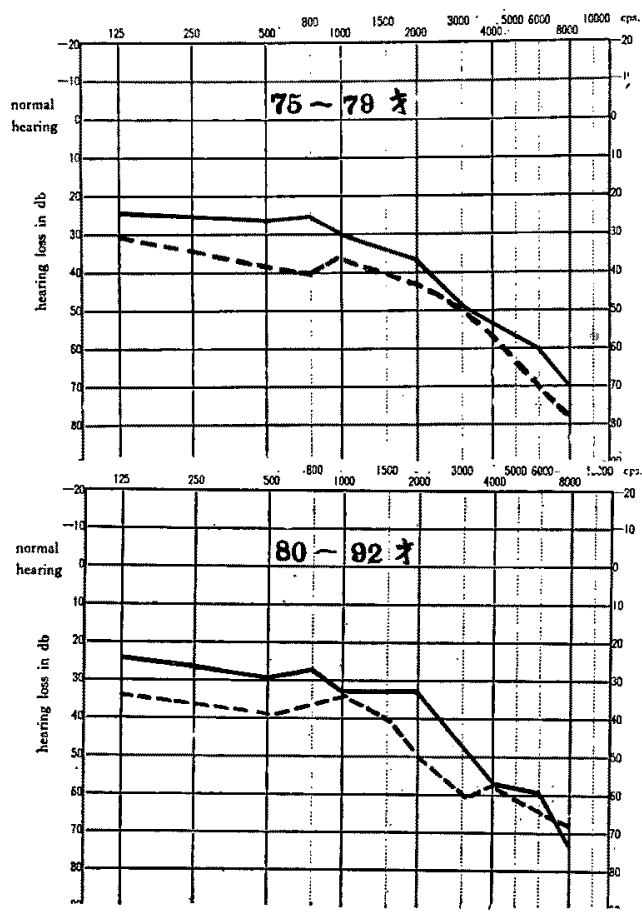

29才以下はすべて正常耳であり，年令の增加と共正 常耳は少くなり，70才以上には正常耳は見られない。 30 才須から高音漸傾型が現九初め，年と共火增加し， 総計では正常耳の半数を占める. 高音急整型8 30 䪱 から少しぶつ見られ，55才以上では水平型路年斯 多くなつている.

第 6 項 オージオグラムの対称性，非対称性火 จฟ

老人性難聴は聴力が左右対称的に低下を来すのが特徽 とされれているが，検查の結果第3表の如く，非対称的な ものが 30 才以上に 53 耳 $12.9 \%$ 見られた。 49 才以下で は非対称的なむの左右の㯖力の差が少いので，50才以 上につを対称的なものと非対称的なるのに分けて聴力損 失平均值を比較してみた。この結果をオージオグラムに とつたのか゚第 22〜24 図である５5～59才は非対称的な るのがやや良好であるが，その他の年代は対称的なる の槙力が明らか炕良好である. そこで非詨称的なるのを 除外した平均值オージオグラムが第 25 図である. 第! 図に比しやや良好となる。

男 - 女 $\cdots . .$.

第 2 表 Audiogram $の$ 型

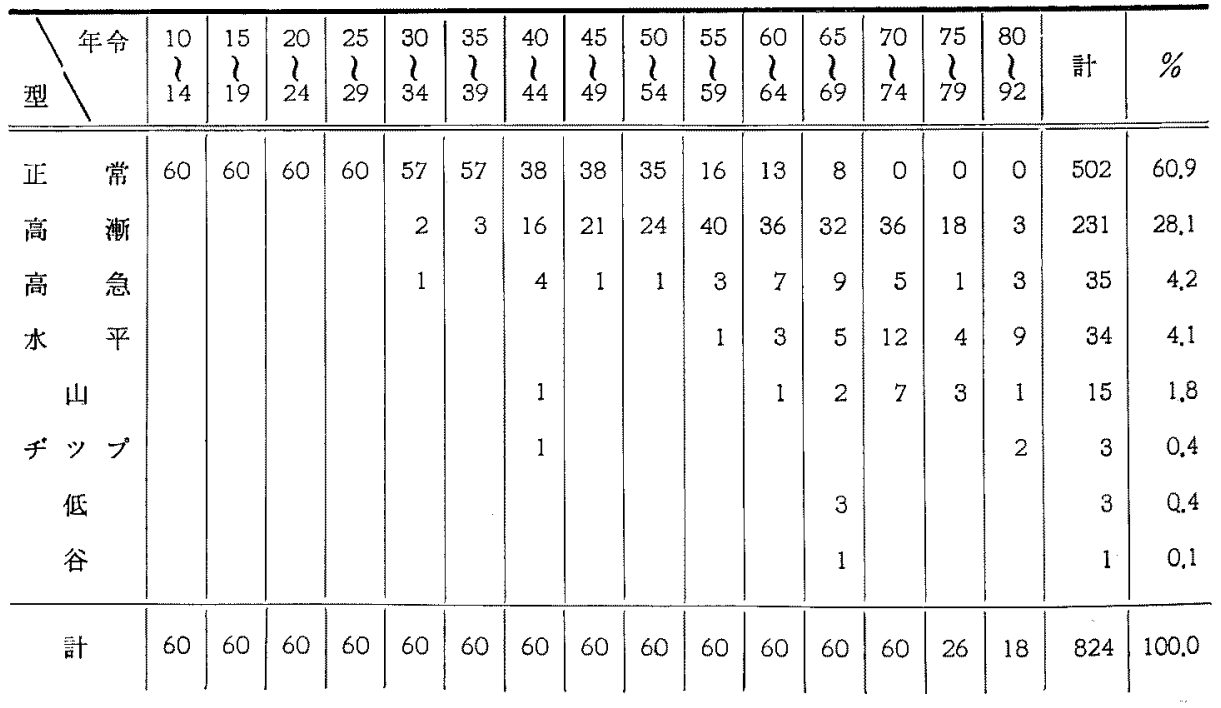


第 3 表 オージオグラムの対称的なもの 非対称的な。

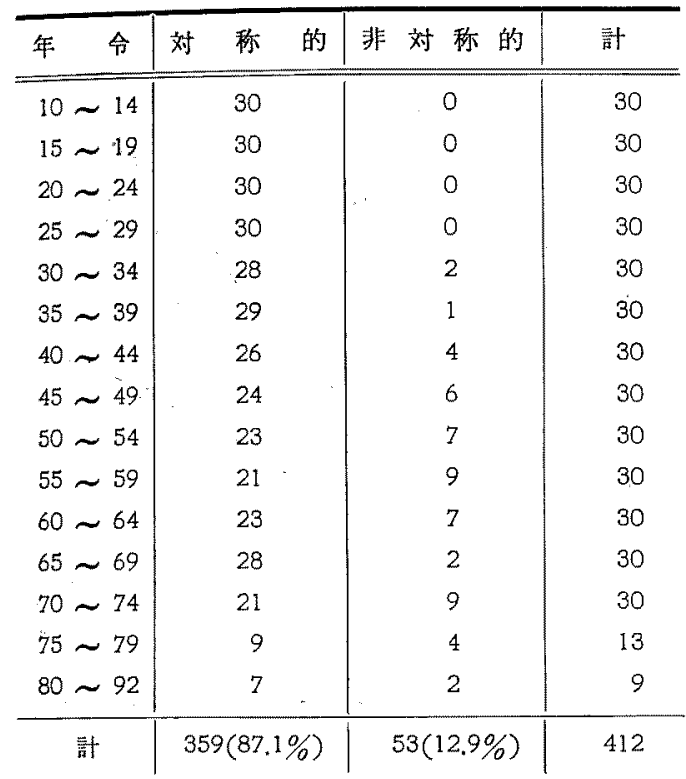

策22图 対称的なものと非対称的なものの 殒均值才ージオグラムの比較
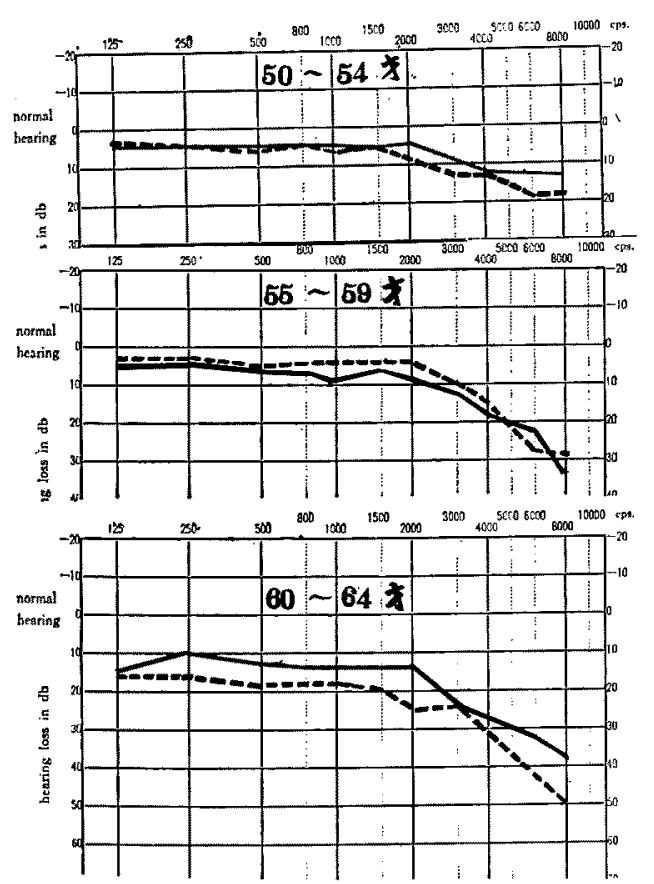

一対称的なもの ……非対称的なもの
第23図 対称的なものと非対称的なるのの 平均值オージオグラムの比較
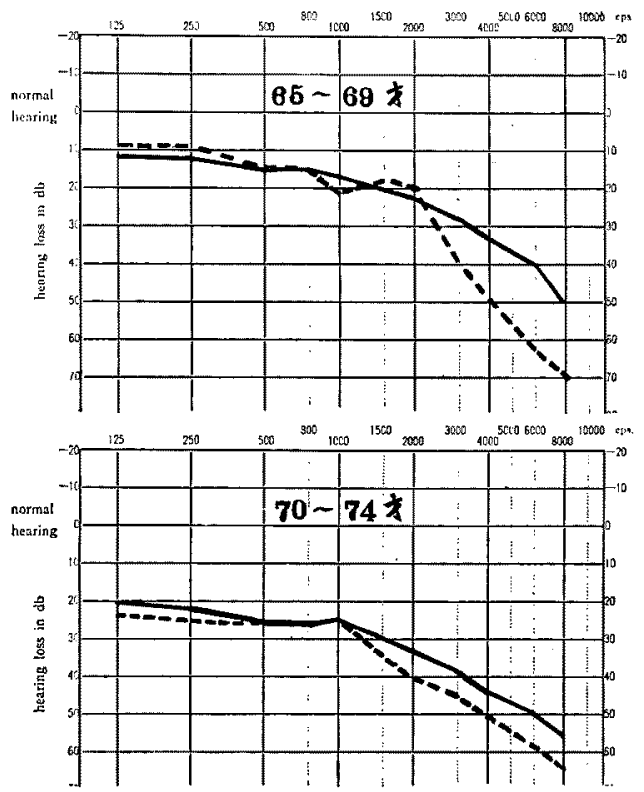

一対称的なむの

第24図 対称的なものと非対称的なるのの 平均值オージオグラムの比較


— 刘称的なもの …. 非対称的なるの 
第25图 平均值オージオグラム （非対称的なるを除外）

AUDiochan



第 4 章 総括並びに考按

老人性難聴は, 老人の他の感覚器の機能減退に伴つ て来る 聴器の老化現象と考号られている．老人性難聴 並びに㯖力の生理的年令変化の臨床的研究は，古くは Bunch (1929) がはじめてオージオィーターによる成績 を発表以来，本邦では吉村（1936）のオトアウヂオンに 上る聴力変化が報告されている，近年オージオメーター の発達，普及に伴つて, Matzker と Kann, Saltzmann, Sataloff $と$ Menduke, Schucknecht, Könnig, Glorig と. Nixon, Fowler, 服部，大木，小山，山本，上野， 小林，設楽，沢木，鈴木，藤崎，真崎等，単に聴力の状 態の報告の灭でなく，動脈硬化その他の疾患との関係等 より詳細な研究活発になつてきた。しかしこのよらに して得られた検查成績を実際にいか処理し，いかに考 えればよいかについては，末た一定の基淮が得られず， 平均值と比較した主観的な判断にまかせている場合が多 い. 著者は以上の検査成結から特にその点について考察 を加えてみた。

1. 聴域平妁值の年令的推移について

10才より80才以上に至る厸範围な年令層にわたつて， 5 年毎の各群に 分けて各群 30 例 60 耳の聴域平均值を算 定した著者の成續は，その二三の周波数について第 2 図 に示したよらに，50才を境にしてそれ以下は漸增の， それ以上は急增のはぼ直線的な折線を示している。この 図によつてのみ解釈すれば，聴域の年令的変化は二つの phase を示すといえる。この曲線を従来報告されていた 諸家の成績と対比すると，4000 cps についての関係を第 26 図（国内文献，海外交献より）に示したよらに，い
第26图 $4000 \mathrm{cps}$ に打ける域值の年令变化の比较 （海外，国内文献上り）

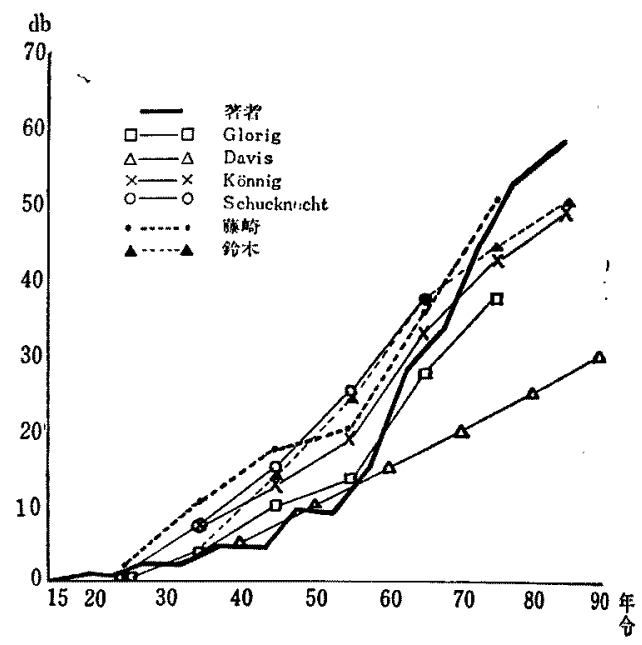

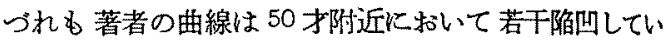
る事が分る，この相異が何故に生じかを速断する事はで きないが著者はその一つの因として疾患の時代的変貌を あげる事ができないかと考党てみた。いかなる疾患です 时代の流れによつて，その病像は種々の変化を示するの であるが，特に最近数年㸝至十数年間の変化は著しいも のである. 中でも平均寿命の延長に伴う老人病の変貌は 見逃す事ができない，症例の撰択にも特殊性はなく，又 各 5 年間に 30 例 60 耳を平均した值である以上，単なる 湘定誤差とは思えない。

最近聴力の生理的年令变化を，一つの数式として表現 する事が考えられ，Davis 及び Glorig 等によつてそれ ぞれ方法が発表された。

Davis の式は，40才以上に郝ける生理的聴力損失平 均值は， 40 才の聴力損失平均值，即ち $\frac{\mathrm{C}_{2}+\mathrm{C}_{5}+\mathrm{C}_{4}}{3}$ 基準にして， $\frac{\mathrm{C}_{2}+\mathrm{C}_{3}+\mathrm{C}_{4}}{3}+\frac{1}{2} \mathrm{db} \times(40$ 才を越光た 年数)である.

Glorig の式は， log median hearing level = b log age $+\log$ a (a と b は各周波数から算定された一定し た值)である。

これら2つの式によつて計算された曲線を，第26四 に示して著者の成繢と比較したが，Davis のむのとはか なり異つているが， Glorig のものとはかなり近似して をり，これは Glorig の式が極めて多数の精選された症 例から計算された式である事と，又年代的にも最近のる 
のである点によるものと思われた。

いるれにしても著者の成績による時は，50才前後の 聴力变化は，少くともその平均值の及を対象とするなら ば，極めて微々たるるのであつて，殆ど問題にする必要 はないと考学られる。

\section{2. 分散について}

古くより聴域の年令による変化は，域值の上算と共に その分散が大になる事が知られている。文献に見られた 諸家の報告例を見てむその点は明らかであるが，著者は 特にこの点について詳紐に検討するために，標集偏差を 求めてそれから F 表によつて分散度の差を検討した。 その結果は第 3 図より第 17 因までに示したように，高 音域炕おいては既炕40才代より，低音域でも55 才上り その分散は少くとる15〜19才の群のそれと同一母集団 に属するるのの分散であるとは云えない結果である事が 分つた。 これらの点より20才代，30才代の所謂平均域 值と，50才代，60才代の平均域值とは，その值を同等 に評価，比較する事は妥当でないと思われた。

次第 27 図，28 図に示したように，域値の变化はた た箪にその分散の程度が異るのみでなく，その分散の形 が異る事も注意しなければならない 例えば $1000 \mathrm{cps,}$ 4000cps について云えば，10 30才位迄は平均值の所 に明嘹なピークを示す形の 分散であるが，30 才を越す とその山の右肩が上がつて来る，更に50 才を越す頃に

第27图 $1000 \mathrm{cps}$ に打ける域值の分布図
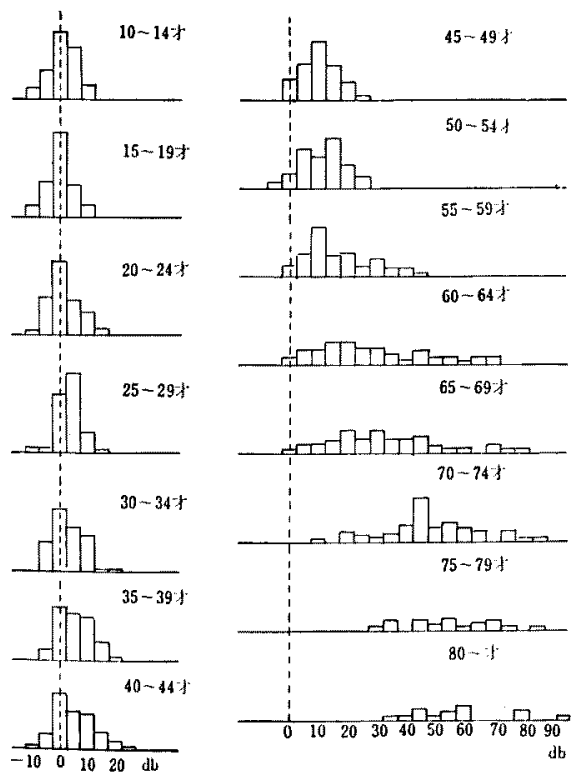

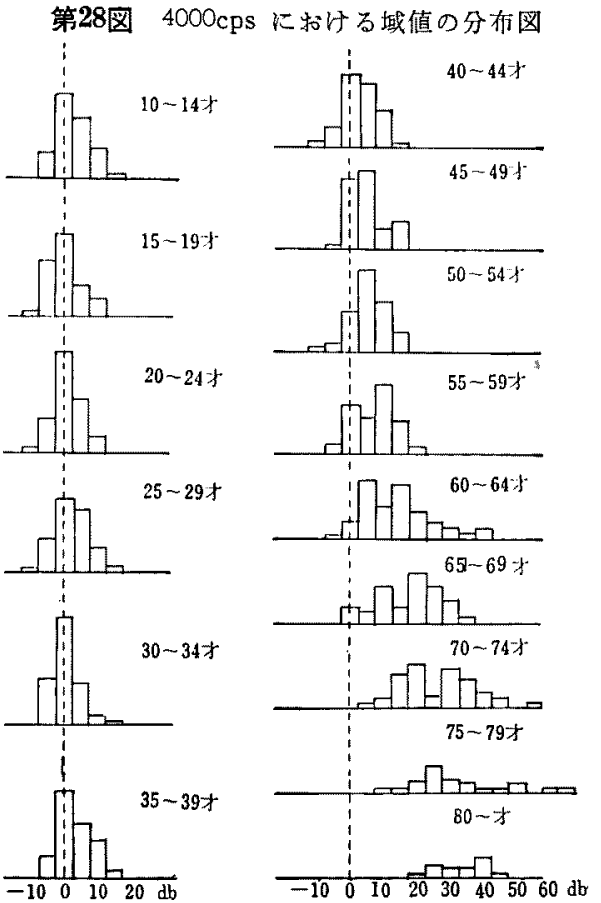

第29图分布曲線

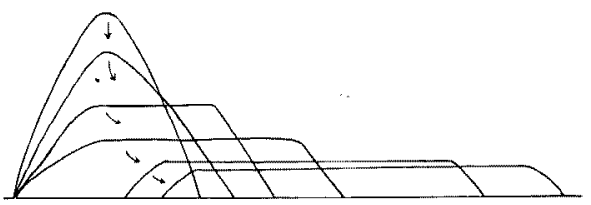

なるとそのまま山が押しつぶされたような形になつてひ ろがつて来る，更に60才を越卞と全体が平たく広くの びて，明らかなピークを認め難くなる傾问を有する（第 29 図).

これらの所見は程度の差こそあれ各周波数について認 めら礼るるので，このよらな形こそ㯖域の生理的年令㚆 化の堅態を示しているものと云ら事がでさる，即ち，分 散のピークは45才迄は殆ど変らない４5才を過ぎると 若干移動して来，60才を過ざるとピークは消失するの である。

\section{3. 男女の差について}

山本は男の聴力の方が良好としているが，一つづつの 周波数についてみると，低音域では悪いが高音域ではむ しろ女の方が良好である。設楽は61〜70才の 4000cps と $8000 \mathrm{cps}$ との関係において，4000cps のばらつきが 男は女より币広く㯖力低下者が多い.8000 cps では同じ 
值を示すが $4000 \mathrm{cps}$ では女の方がよいと報告している. Sataloff と Menduke む6 才では女の聴力がよく，76 才以下では女は男よりも聴力損失は少い之述べてをり， Schucknecht の例では女が遥に良好である，Bunch の 白人に拈ける報告では，低音域では女は男よりやや劣る が，高音域に括いては妨良好となつている，本例にお いては50才代では低音域では男の方が良いが，高普域 では女の方が良好となのてをり，60才以上の年代に和 いては女の方がすべてよい，一般に女が長命であるとい ら事は，聴器の老化現象も男に比しておそく，又騥音そ の他による影響等も比較的少いといら事であるらか，

4. オージオグラムの型について

高晏漸傾型が年と共に多くなるのは，老人性難㯖の性 格から考えて当然の事であり，高令になり水平型が兒れ て来るのむ, 德力障碍が高音域から低音域への波及とみ なしてよいと思われる。

5. 対称性について

老人性難㯖は，聴力が対称的に低下していくのが普通 の型といわれている. 非対称的に低下していくものにつ いてみると，一側の聴力が対称的なるのに比して大分覀 い事から，自覚しない病的な要因があるのではないかと 推察された。

6. 所謂聴力の生理的年令変化について

身体一般の諸機能と相まつて, 聴力が年令と共墨化 する事は既によく知られた事実であり，その実態につい ても多くの報告がある。しかし作らその場合それをいか に理解し，いかに処理するかについては異論が多い，例 えば老人に和いて若干の域值の悪化があつた場合に，そ れを生理的変化を考えるべきか，又その限界を何によつ て求めればよいか，あるいは例之ば瞕業性難聴等の加 く, 年含 (勤務年数) と共に漸次悪化を示す疾患等の時 に，艺の中の生理的な部分をいかに考点，いかに処理す ればよいか等々である。

最も簡単な方法は平均值をもつてそれを表現する馬 でこの方法によればその数值そのるのについては種々 異論もあるが，処理は簡単であり，古くより一般にこの 方法がとられていた。しいし最近特にこの分散が問題之 なる事が多く，若年者と高年者とでは単に平均値が異る のみでなく, 分散が異るので, 平均值のみをむつて単純 にそれを考光事脮当ではないとの考党が持たれるよ らになつた。

在く最近藤崎は, その分散を推計学的に処理して寨却 限界を算出し，それによつて生理的な变化と病的な変化
を区別する覀事を提案している，これらの考古方は，従来 の平均値のみを以て考えた考え方よりは一歩前進したも のと云ら事ができるが，高合者になるとその分散の量， 質ともに大きく変化して来る等を考えれば，決して充分 に妥当な万法とは云えない。

以上の上うな点から，著者は高令者の聼力を，その平 均值，むるいは分散といら立場から表現する牙はできる が，それを以て生理的，病的と規制する事はできないと 考えた。即ちそのためには，平均值，標準䖍差，裹却限 界等の数量的な処理よりも，その障碍の形や性啠, 内容 に対する詳紐な追求が先づなされなければならない。

\section{第 5 章 結 論}

聴賞に関するる自覚症，㯖力に影響を及ぼすような耳科 的既往歴がなく，耳鏡検査で 致膜に病的所見のない10 才から92才迄，412名824耳について聴力澌定を行つ た結果から下記の結論を得た。

1. 聴域平均值は年令の進さにつれて 漸次悪化する. その悪化の模様には次のよらな特徽がある。

(1) 高音程著明である.

(2) 50 才前後迄は極く軽微であるが，それを過ぎ ると著明となる。

（3）従来の諸報告に比べて50才前後迄はむしろ少 く，それ以上では大きい。

2. 聴域の個人別分散は年令の進むにつれて漸次大上 なる、それには次のような特徽がある。

(1) 高音程著明である。

（2）初めその分散は平均值に鋭いピークを示したも のが，やがてその形がくづれ，最後には広、箸 囲にわたるぱらつきとなつてピークは消失才 万.

3. 性別の相異は著明ではないが，女性の方が若干覀 化の傾向が少い。

4. 聴力型は漸攧型が殆どである.

5. 左右聴像は対称性を示するのが $87.1 \%$ で, 非対称 の型を示すものは，対称的な聴像を示するのよりも聴力 の带いもの多い.

6. 以上の点より，年令炕る生理的聴力变化を，そ の平均値, 標蕉偏差あるいは棄却限界等をむつての表 現する事は妥当でなく，又誤りを生ずる原因になり得 b.

\section{第 6 章 文献}

1) C.C. Bunch: Further observations on age variations in auditory acuity. Arch. Otolar. 13: 
170, 1931. 2) C.C. Bunch: Age variations in auditory. Arch. Otolar. 9: 625, $1929 . \quad$ 3) C.C. Bunch and J.S. Raiford: Race and sex variations in auditory acuity. Arch. Otolar. $13: 423,1931$. 4) Edmund Prince Fowler: Presbyacusis, the aging ear. Ann. O.R.L. 68: 764, 1959. 5) Aram Glorig and James Nixon: Hearing loss as a function of age. Lar. 72 : 1596, $1962 . \quad$ 6) E. König: Pitch discrimination and age. Acta Otolar. 48: 475, 1958. 7) J. Matzker and H. Kann: On medical modifcation of presbyacusis. Zeitsch. R.O. 40: 468, 1961. 8) A.J. Philipszoon: On the Cause of presbyacusis-a Case of unequal presbyacusis of both ears. J. Lar-Otol. 76:593, 1962. 9) Maurice Saltzmann: Presbyacusis. Arch. Otolar. 66: 67, 1957. Joseph Sataloff and H. Menduke: Presbyacusis. Arch. Otolar. 66: 271, $1957 . \quad 11)$ Harold $F$. Schucknecht: Presbyacusis. Lar. 65: 402, 1955. 12) Hallowell Davis: Missouri Senate Bill No 167 concerning industrial hearing loss. Arch. Otolar. $72: 87,1960$. 13) 吉村宗次： st 6 型「オトアウヂオ ソ」による正常並びに病的聴力曲線，日耳尖，42；794，

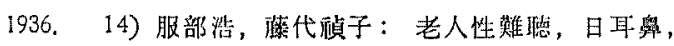
$56 ; 657,1953$. 15) 小山洗輝：老人性難㯖につい

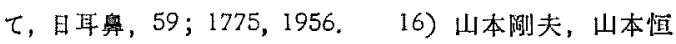

子：老人性難聴に関する研究，国民街生，26；127， 1957. 17) 上野正一郎；Audiogramに括ける $\mathrm{C}_{5} \mathrm{dip}$ に関する砄究，第 2 報 老人の聴觉と老人性難㯖，日耳 離，61；1535，1958.18）小林恒久：老人性難聴に 関する研究，日耳鼻，61；157，1958。19）梖崎和夫： Audiogram の生理的年令 推移，日耳鬼，62；1797, 1959. 20) 設楽哲也：日本人高令者の聴力に関する 研究，日耳鬼，63；1551，1960，21）鉿木敬：恥力 の年令变化の研扎，日耳舅，62；2253，1959。“22) 設集哲也，沢木修二，藤田史朗：高令者の聴力につい ての再検，オージオロージー，1；84，1958，23) 滕 崎茂已，酒井俊一，谷口武浐：老人性難聴の生理的限 界について，日耳鼻，66；41，1963，24）大木稳文： 日本人に扣ける所謂老人性難㯖の臨床的観察，医療，8; 䠛時增刊号, 188, 1954.

榴を終るに当り，御指導，御校閲を睗わりま した栗田口省吾教授，立木孝助教授に㳭謝する と共に，研焱に際し御便宜，御频婞を頂いた原 出隆笪博士に心から感謝致します

本諭文の要旨は第13回東北耳睤䁌喉科連合学 会に打いて器裴した。

（原精到着 $=$ 昭和 39.3.12 日） 